Apele, komunikaty, sprawozdania

DOI: http://dx.doi.org/10.30747/bfgez.66.2016.16

\title{
ABY NIE ZAGINĘŁA PAMIĘĆ!
}

Muzeum Wojskowej Służby Polek w Toruniu (pierwsze i jedyne $\mathrm{w}$ Polsce muzeum o takim profilu), jest jedną $\mathrm{z}$ form działalności istniejącej od ponad 25 lat Fundacji „Archiwum i Muzeum Pomorskie AK oraz Wojskowej Służby Polek" (od 2009 r. Fundacja Generał Elżbiety Zawackiej). Z inicjatywy prof. Elżbiety Zawackiej uchwałą Rady Fundacji z dnia 17 VI 2002 r. został rozszerzony zakres działalności Fundacji, która oprócz gromadzenia, przechowywania, opracowywania i udostępniania archiwaliów, gromadzi wszelkiego rodzaju eksponaty muzealne odzwierciedlające Służbę Polek w wojsku oraz ich udział w walkach niepodległościowych, również eksponaty dotyczące konspiracji pomorskiej. Przez lata w zbiorach Fundacji zgromadzono wiele bardzo cennych eksponatów, które wcześniej prezentowane były przy okazji corocznych sesji jedynie niewielkiemu gronu odbiorców. Dzięki staraniom prof. E. Zawackiej, przy współpracy z toruńskim Muzeum Okręgowym, Muzeum Tradycji Pomorskiego Okręgu Wojskowego w Bydgoszczy i Archiwum Akt Nowych w Warszawie stało się możliwe przygotowanie wystawy „Wojskowa Służba Polek" (kurator: Anna Jurkiewicz). Jej otwarcie połączono z XII sesją popularnonaukową oraz III Zjazdem Kombatantek (16 listopada 2002 r.), a ekspozycja znajdowała się w Domu Eskenów, ul. Łazienna 16. Członkinie Memoriału Generał Marii Wittek z Warszawy z inicjatywy Eugenii Szymczak przekazały na tę okoliczność w darze dla muzeum Wojskowej Służby Polek kopię modelu pomnika łączniczki AK, którego oryginał znajduje się w Józefowie. Jerzy Jurandot w wierszu "Żołnierzu-panienko" upamiętnił łączniczki:

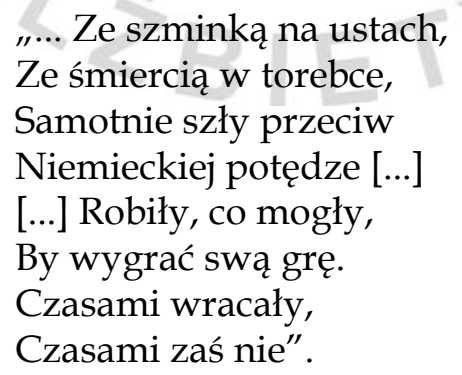

W dniach od 13 lutego do 31 III 2002 r. naszą wystawę mogli obejrzeć również mieszkańcy Trójmiasta (Gdynia, Franciszkańskie Centrum Kultury). W roku 2005 w Muzeum Wojska Polskiego w Warszawie odbyła się wystawa pt. „Szminka i karabin - Kobiety polskie na frontach 
II wojny światowej w 60. rocznicę jej zakończenia". Wystawa była zorganizowana przy współudziale Fundacji. Następną dużą ekspozycję zorganizowano w nowej siedzibie Fundacji, ul. Podmurna 93, w 2008 r., wystawa „Polka 1939-1945, czyli kilka słów o wojennej służbie Polek” w 99. urodziny gen. prof. Elżbiety Zawackiej (kuratorem wystawy była Katarzyna Minczykowska). Wystawa „Minęło sto lat... 1909-2009. Kilka obrazów z życia gen. Elżbiety Zawackiej" była prezentowana w wielu miejscowościach w kraju i za granicą (kurator: K. Minczykowska). Muzeum Wojskowej Służby Polek nie mogłoby się rozwijać bez pomocy członków Koła Przyjaciół Memoriału Generał Marii Wittek. To dzięki darczyńcom - kombatantom i ich rodzinom - dotychczas zostały zgromadzone 503 eksponaty. Z okresu międzywojennego pochodzą zdjęcia z obozów PWK w Garczynie, Spale i in. (zbiór albumów, ręcznie pisane i malowane przez pewiaczki kroniki obozowe i śpiewniki). Pewiaczka Aniela Sitko-Harasim, uczestniczka obozów PWK w Garczynie ofiarowała pas skórzany z klamrą od munduru z 1938 r., a także łyżkę stołową z obozu. Z konspiracji pomorskiej zgromadzono fotografie domów, kamienic w Toruniu, gdzie mieściły się kwatery - lokale konspiracyjne AK. Zbiór obejmuje 29 obiektów codziennego użytku prezentowanych na wystawie "Śladami konspiracji toruńskiej 1939-1945". Są też drobne przedmioty służące do ukrywania grypsów (cygarniczka, ołówek), także klucz z ukrytą skrętką do konspiracyjnej poczty, należący do Marii Wittek, szefa WSK. Do najcenniejszych eksponatów należy aparat nadawczoodbiorczy (radiostacja), który w 1944 r., który przekazał Fundacji kierownik Bazy Łączności Zagranicznej w Paryżu kryptonim „Janka”, por. Józef Kopyto. W zbiorach Fundacji są dobrze zachowane oryginalne mundury kobiet-żołnierzy różnych formacji: LWP, PWSK, AK, np. mundur por. Józefy Fabian-Janus z I Armii WP z 1943 r., kpt. Eugenii Barabasz, ppor. Anny Borkowskiej z brygady saperów, która przeszła szlak bojowy od Lenino do Berlina, mundur wyjściowy por. Zofii Sączowskiej-Łukianiec, komendantki 316. i 317. Kompanii Transportowej, mundur Henryki Sokuł (vel Sokół), komendantki 318. Kompanii Kantyn Polowych (PWSK), oraz dwa mundury kobiet walczących pod Monte Cassino, pielęgniarki Aleksandry Zduńczyk-Siedleckiej oraz mundur z kaburą, dwa mundury kobiet AK Danuty Ruteckiej i Wandy Domanowskiej. Kopie mundurów PLSK, PMSK i in. są udostępniane dzieciom i młodzieży w trakcie prowadzonych warsztatów historycznych w Fundacji. Muzeum w gromadzonych zbiorach posiada śpiwór brezentowy typ „Kit Beck”, należący do Józefy Błaszczyszyn z 316. Kompanii Transportowej. Wśród pamiątek jest wiele odznaczeń: Defence Medal, War Medal, odznaka Ankenbes Narwik Beisfiord (1940), należące do kpt. Haliny Poliszewskiej z 1. Dyw. Pancernej pod dowództwem gen. Stanisława Maczka. Szczególnie robią 
wrażenie i wzruszają pamiątki „rękodzieła” kobiet-żołnierzy z niemieckich i sowieckich więzień i obozów. To 21 figurek wykonanych ręcznie $\mathrm{z}$ chleba więziennego $\mathrm{w}$ więzieniu na Łukiszkach w Wilnie w latach 1942-1943 przez Janinę i Władysławę Rusieckie, różaniec i broszka (także z chleba) wykonane przez Danutę Przystasz w więzieniu w Warszawie przy Rakowieckiej. Modlitwy i prośby: „Boże pozwól nam wrócić do wolnej Polski" pisane na skrawkach płótna przez kobiety-żołnierzy AK z obozu INTA (1945-1955) zesłane przez NKWD na Syberię. Wśród eksponatów jest kilka pamiątek z okresu Powstania Warszawskiego, m.in. torba sanitarna - dar sanitariuszki AK Stanisławy Grabowskiej, krzyż, na który składała przysięgę Janina Hartman - żołnierz AK, oraz oryginalne biało-czerwone opaski powstańców.

W Fundacji znajduje się rekonstrukcja saloniku prof. gen. Elżbiety Zawackiej oraz wszystkie jej odznaczenia (w tym Ordery: Orła Białego i Polonia Restituta oraz odznaka spadochronowa cichociemnej).

Fundacja Generał Elżbiety Zawackiej serdecznie dziękuje wszystkim darczyńcom $i$ ich rodzinom za przekazywane pamiątki (już od 1990 r. i w latach następnych), wzbogacające zbiory Muzeum Wojskowej Służby Polek. Materiały, eksponaty prezentowane na wystawach dają świadectwo o naszej przeszłości. Pragniemy, by ocaliły od zapomnienia ważne dla historii postaci kobiet-żołnierzy.

W rękach osób prywatnych znajduje się jeszcze wiele cennych przedmiotów, które warto pozyskać dla naszego Muzeum. Prosimy o pomoc nie tylko Kombatantów, ale także osoby, które w swoich środowiskach mogą współdziałać z nami na rzecz pozyskania nowych eksponatów. Muzeum Wojskowej Służby Polek od początku cieszy się popularnością. Zapraszamy i czekamy na zwiedzających z całej Polski i zagranicy. W lutym 2015 r. Halina Rozmarynowska, lat 92, członkini Memoriału Generał Marii Wittek, przedwojenna członkini PWK z Grodna, obrońca 1939 r., sanitariuszka LWP ofiarowała swój mundur do zbiorów naszego Muzeum. Dziękujemy! Kolejno dokumentalistami odpowiedzialnymi za zbiory Muzeum byli: Michał Ojczyk, Anna Jurkiewicz, Anna Rojewska, obecnie Anna Mikulska. 